\title{
Intrauterine ozone treatment of puerperal disorders in domestic ruminants: a review
}

\author{
Marko Samardžija ${ }^{1 *}$, Romana Turk ${ }^{2}$, Przemyslaw Sobiech ${ }^{3}$, \\ Hrvoje Valpotićc ${ }^{4}$ Ivica Harapin ${ }^{5}$, Damjan Gračner ${ }^{5}$, and Dražen Đuričićc
}

${ }^{I}$ Clinic of Obstetrics and Reproduction, Faculty of Veterinary Medicine, University of Zagreb, Croatia

${ }^{2}$ Department for Pathophysiology, Faculty of Veterinary Medicine, University of Zagreb, Zagreb, Croatia

${ }^{3}$ Department for Internal Diseases, Faculty of Veterinary Medicine, University of Warmia and Mazury in Olsztyn, Olsztyn, Poland

${ }^{4}$ Department for Nutrition and Animal Husbandry, Faculty of Veterinary Medicine, University of Zagreb, Zagreb, Croatia

${ }^{5}$ Clinic for Internal Diseases, Faculty of Veterinary Medicine, University of Zagreb, Zagreb, Croatia

${ }^{6}$ Veterinary Practice Đurđevac, Đurđevac, Croatia

SAMARDŽIJA, M., R. TURK, P. SOBIECH, H. VALPOTIĆ, I. HARAPIN, D. GRAČNER, D. ĐURIČIIĆ: Intrauterine ozone treatment of puerperal disorders in domestic ruminants: a review. Vet. arhiv 87, 363-375, 2017.

\section{ABSTRACT}

In the fight against infectious diseases, with the combined efforts of basic and clinical veterinary scientists, practitioners and domestic animal producers, antimicrobials of natural origin will bring to veterinary medicine the same type of curative revolution as antibiotics did. To realize the main objective of animal husbandry, in diminishing negative economic trends, it is necessary to introduce contemporary management to reproduction. Amongst the numerous preventive measures in use in practice, it is also important to use alternative preparations such as ozone, which has germicidal and fungicidal activities. Ozone is frequently used within the field of veterinary medicine for prophylaxis/treatment of pathological conditions of the genital system in domestic ruminants, such as retained fetal membranes, clinical metritis/endometritis, and improvement of fertility, according to some previous studies. The advantages of ozone in comparison to antibiotics are usage without prescription, low medication costs, lack of bacterial resistance, and the absence of residues in animal products. However, ozone is frequently but still insufficiently used in veterinary practice, particularly in buiatrics. More recently, it has exhibited very promising results in treatment of puerperal disorders in cows, goats and sheep as an alternative to the use of antibiotics, which are restricted and/or being gradually withdrawn in production of food animals in the EU.

Key words: ozone treatment, puerperium disorders, ruminants

\footnotetext{
*Corresponding author:

Prof. Dr. Marko Samardžija, Clinic of Obstetrics and Reproduction, Faculty of Veterinary Medicine, University of Zagreb, Heinzelova 55, 10000 Zagreb, Croatia; Phone: +385 12390 2321; Fax: +385 1244 1390; E-mail: smarko@vef.hr
} 


\section{Introduction}

The future of successful cattle breeding worldwide is based on continual and professional breeding procedures. On dairy farms, milk production is continuously increasing, but fertility is simultaneously decreasing (LÓPEZ-GATIUS et al., 2006; SAMARDŽIJA et al., 2008). The challenges of getting high yielding dairy cows pregnant are becoming increasingly important (WEIGEL, 2006). This is of particular importance in reproductive management in buiatrics, where ozone has been used as an alternative to antibiotics due to its germicidal/fungicidal activities (DJURICIC et al., 2012a).

\section{Reproductive parameters in ruminants}

In order to be able to evaluate bovine fertility in intensive and extensive farming systems different parameters have been suggested such as duration of days open or service period, conception rate and pregnancy rate following first insemination (PRYCE at al., 2004; DOBRANIĆ et al., 2008). The aim of cattle production is to shorten the duration of days open or the intercalving interval to about 1 year, depending on milk yield (SAMARDŽIJA et al., 2008). Therefore, proper management of dairy cows, especially before calving, is of the great importance in order to prevent dystocia, puerperal diseases and metabolic disorders that often lead to major economic losses (KOČILA et al., 2009).

Fertility in goats is determined by the age of goats at first kidding, kidding interval, type of birth, litter size, kid body weight at birth and weaning (SONG et al., 2006). Reproductive performance is the productivity of the animal, the herd or the flock in terms of offspring produced, and may be expressed in many ways such as: prolificacy, fertility, fecundity, interkidding interval and days open. Prolificacy, fertility and fecundity in small ruminants vary in relation to breed, season, age, nutritional status, health, breeding management and farm supplies (ĐURIČIĆ et al., 2012).

\section{The transition period in cows}

The critical phase around the calving period (three weeks before and three weeks after delivery) is defined as the transition period. During the last three weeks of pregnancy, the endocrine status of cows changes quickly in order to prepare the animals for the upcoming lactation (FOLNOŽIĆ et al., 2015). During that period animals are very sensitive and special care has to be taken in housing and feeding (LeBLANC, 2010). Food intake is increased to meet the needs of the fetus for growth and development, and also to prepare the udder for lactation, but unfortunately it often decreases. Dry matter intake is lower than the requirements of the body, and therefore body reserves are mobilized (GONZALEZ et al., 2011). Most diseases that may cause long-term infertility in cows occur in the peripartal or transition periods (DOBRANIĆ et al., 2008).

Major reproductive disorders in the periparturient period in goats are abortion, retained fetal membrane (RFM) and stillbirths, which may negatively influence their health, reproductive efficacy and welfare (AHMAD et al., 2007). The most frequently 
observed reproductive complications in goats are abortion (20\%), RFM (10\%), dystocia (10\%), stillbirths (10\%) and mastitis (10\%) (MUDE and WAGHMARE, 2010).

Retention of fetal membranes (RFM)

The RFM in cows is a pathological condition defined as the absence of fetal membrane expulsion within 12 to 24 hours after calving, caused by the failure of the third stage of labor, due to various causes (GAUTAM et al., 2009). The fetal membrane is usually expelled 6 to 8 hours after calving in approximately $80 \%$ of cows (VAN WERVEN et al., 1992). The incidence of RFM in cows is between 5\%-10\%, depending on the herd (LeBLANC, 2008). Although the causes of primary RFM are not fully understood, the main cause of RFM is definitely connected with structural changes in the fetoplacental unit and certain hormonal changes (LAVEN and PETERS, 1996). Secondary RFM is a consequence of a hypotonic or atonic uterus, whereas primary retention appears as a result of cotyledon-caruncle attachments which may fail to relax. The RFM delays uterine involution and could lead to clinical metritis and endometritis, resulting in subfertility/infertility (GAUTAM et al., 2009), which are the most common causes of infertility in dairy cattle (LAVEN and PETERS, 1996; LEWIS, 1997; SHELDON and DOBSON, 2004). Clinical metritis is a consequence of $25 \%$ RFM after parturition, and the main reason for subfertility in cows due to slower involution of the uterus and the return of ovarian cyclicity (DINSMORE et al., 1996). It is well known that cows with RFM have a higher bacterial count in the uterus such as: E. coli, Clostridium spp. and Gram-negative anaerobes in comparison to cows with normal puerperium. This increases the risk of development of inflammation of the uterus (MATEUS et al., 2002). Many authors have confirmed prolonged intercalving interval, days open and conception rate as a consequence of RFM (GAUTAM et al., 2009). The efficacy of intrauterine administration of antibiotics for treatment of RFM has been questioned due to the multiple interactions of antibiotic substances with uterine contents, and the varying degrees of absorption (EILER, 1997). It has been demonstrated that there is a high risk for residues in milk, especially with extra-label drug administration, thus alternative approaches are being sought to treat RFM (DINSMORE et al., 1996).

One of these alternatives includes ozone preparations (DJURICIC et al., 2012a; 2012b; ZOBEL and TKALCIC, 2013; DJURICIC et al., 2015).

RFM in goats is defined as the failure of fetal membrane expulsion within 6-8 hours after kidding (NOAKES et al., 2009; SAMARDŽIJA et al., 2010) and veterinary attention should be sought if they are not expelled within 12 hours. After this time, immediate veterinary intervention is necessary (MATTHEWS, 2009). The incidence of RFM in goats varies from 2\%-10\% depending on the herd (MUDE and WAGHMARE, 2010; AMEEN and AJAYI, 2013).

\section{Clinical metritis and endometritis}

Some of the common causes of dairy cow infertility, amongst others, are clinical metritis and endometritis (GAUTAM et al., 2009). Clinical metritis is an acute systemic 
illness due to infection of the uterus with bacteria, usually within 10 days after parturition (SHELDON et al., 2006; LeBLANC, 2008; ĐURIČIĆ et al., 2012). All layers of the uterine wall show evidence of inflammation, such as edema, infiltration of leukocytes, and myometrium degeneration. In both conditions, the mucosa is congested, and severe leukocyte infiltration begins, in response to common pathogens such as: Trueperella (T) pyogenes, F. necrophorum and E. coli. Treatment of clinical metritis has been reviewed recently by SZENCI (2014) and SZENCI et al. (2015).

Clinical endometritis is an inflammation of the endometrium with mucous, and mucopurulent to purulent vaginal discharge, that appears three weeks after parturition or later (SHELDON and DOBSON, 2004). The inflammation is caused by bacteria, fungi or mycoplasmas. The causative agents ascend through the open cervix during parturition or early puerperium. Clinical endometritis which appears later is usually caused by RFM. The external signs of the disease can be seen during the first ovulation or after resumption of ovarian cyclicity (SHELDON et al., 2004). Clinical endometritis is observed in $15 \%$ $20 \%$ of cows, 4-6 weeks after parturition, and subclinical endometritis is noted in $30 \%$ $35 \%$ of cows between 4-9 weeks after parturition (LeBLANC, 2008). Clinical endometritis is usually caused by coliform Gram-negative anaerobic bacteria, T. pyogenes and others (AZAWI, 2008). The therapy for clinical endometritis is applied depending on the course of the disease, and should be directed to improvement of fertility, and at the same time to eliminate the causative agents from the uterus by medication as soon as possible. The success of therapy is evaluated by elimination of the uterine discharge, the sensitivity of causative agents to the treatment, the concentration of the drug applied, and exposure of the endometrium to this drug (NOAKES et al., 2009). Therapy is primarily based on local application of antibiotic preparations, and selection of antibiotics should be based on determination of antibiotic resistance. Furthermore, antibiotic preparations have different absorption properties and induce multiple interactions within the uterus (DRILLICH et al., 2001). Besides antibiotic therapy, prostaglandins and/or antiseptic agents have been recently reviewed by SASSI et al. (2010). According to our recent findings, intrauterine ozone treatment may also be used (ZOBEL, 2013; ĐURIČIĆ et al., 2014). Clinical endometritis can prolong days open, the intercalving interval, increase the number of inseminations per pregnancy and the risk of cows being culled for infertility. On average, $32.6 \%$ of cows may have vaginal discharge (from mucopurulent to purulent) within the first two months after parturition, but only about $25.9 \%$ cows have visible clinical signs of disturbances in their general health status. More than $61 \%$ of these cows have a lower conception rate and days open longer than 205 days (GAUTAM et al., 2009). Hence, it is very important to perform vaginal examination of cow between days 21 and 25 following parturition, in order to diagnose clinical endometritis as early as possible and to start therapy if necessary (ĐURIČIĆ et al., 2015). 


\section{Use of ozone preparations in ruminants}

Ozone is a gaseous molecule composed of three oxygen atoms $\left(\mathrm{O}_{3}\right)$. Ozone is a very powerful oxidant, which is related to its instability and quick transformation into oxygen (Di PAOLO et al., 2004). These oxidative processes in peroxidase activity may destroy bacterial capsules and cell membranes, and then block DNA replication. Gram-positive bacteria are more sensitive to ozone than Gram-negative. Ozone has germicidal, fungicidal and virucidal activities (BOCCI, 1996). The virucidal activity of ozone is manifested by the inactivation of viruses through agglutination of specific viral receptors on the target cells to which the viruses have affinity. In addition, ozone may induce chemical reactions which may cause metabolic changes, such as: glycolysis, catabolism of lipids and direct lipolytic effect (BOCCI, 1996). It can stimulate activation of lymphocytes or monocytes to release several cytokines, such as: interferon (IFN) $\alpha, \beta, \gamma$, tumor necrosis factor $\alpha$ (TNF $\alpha$ ), interleukins (IL) 1, 2, 4, 6, 8 and 10, granulocyte/monocite colony stimulation factor (GM-CSF), and transforming growth factor $\beta$ (TGF $\beta$ ) (OHTSUKA et al., 2006). Through these actions it acts as an immunomodulator (KORZUN et al., 2008). Ozone may activate the Krebs cycles and stimulate release of enzymes, which can eliminate free oxygen radicals, and thus may protect cells (OZMEN et al., 1993). As reported by BOCCI (1996), ozone is able to inactivate bacteria, spores and viruses in vitro within a few minutes, by destroying the integrity of the bacterial membrane through the oxidative processes of their phospholipids and proteins, while in fungi it acts as an inhibitor to their growth (KORZUN et al., 2008). Furthermore, ozone penetrates into the cells of microorganisms and interacts with molecular structures within the cytoplasm and nucleus (frequently with DNA), and in this way it may interfere with their replication (BOCCI, 1996). The toxicity of ozone towards microorganisms and simultaneous lack of toxicity towards the host cells is explained by the lack of the antioxidative enzymatic mechanisms in viruses, fungi and bacteria, which are characteristics of evolutionary higher organisms (BOCCI, 1999).

The advantages of ozone in comparison to antibiotics are usage without prescription, the absence of adverse effects, lower medication costs, the lack of bacterial resistance, and the absence of residues in milk (DINSMORE et al., 1996), meat and other tissues (DJURICIC et al., 2012a; ZOBEL et al., 2014). In veterinary practice, ozone has been used for more than 30 years. However, the most widespread use of ozone in veterinary practice is for treatment of various pathological conditions of the genital system in domestic ruminants, such as RFM, clinical metritis/endometritis, as well as for improvement of fertility (DJURICIC et al., 2011; 2012a; 2012b; ZOBEL, 2013; ZOBEL and TKALCIC, 2013; ĐURIČIĆ et al., 2014; ZOBEL et al., 2014; ĐURIČIĆ et al., 2015).

There are many different forms of ozone preparations, such as: creams, gas, injections, palettes, foam, pearls and boluses (TRAVAGLI et al., 2009). The major use of ozone in veterinary practice is in the form of foam and pearls for treatment of RFM, clinical metritis and endometritis (SCROLLAVEZZA et al., 1997; MARUSI et al., 1999; MARUSI et al., 2000). 
Intrauterine administration of an ozone spray may shorten days open in cows of Holstein and Simmental breeds (DJURICIC et al., 2012a; 2012b). DJURICIC et al. (2012a), ZOBEL and TKALCIC (2013), DJURICIC et al. (2015) and ĐURIČIĆ et al. (2016) reported the positive effects of ozone treatment of RFM in cows, goats and ewes, as well as of clinical metritis/ endometritis/ in cows and ewes (ĐURIČIĆ et al., 2014; ZOBEL et al., 2014; ĐURIČIĆ et al., 2016). These effects were evident due to the fact that an ozone preparation applied to the uterus resulted in significantly better recovery in relation to the other preparations registered (antibiotics) for treatment of such conditions. None of these studies reported any negative effects of intrauterine application of ozone in cows.

Preventive intrauterine ozone application has varying effects on reproductive performance in dairy cows. Cows treated with an ozone foaming spray between 24-48 hours after calving became pregnant sooner and had a better conception rate than cows treated with ozone pearls. It is assumed that this improvement could be ascribed to the ozone preparation (spray) and the amount of active substance in it. In addition, ozone pearls (a prescribed single dose of 6 pearls) are very small paraffin pearls, moist and crude, and thus they are not able to expand throughout the whole uterus, while the ozone foaming spray fills the entire uterus (DJURICIC et al., 2012b).

In the case of clinical metritis, ozone is applied into the uterus as a foaming spray (Riger Spray $^{\circledR}$, Novagen, Parendzana, Italy) by a catheter, for 8-10 seconds. The same procedure is used for treatment of clinical endometritis, but the cow's uterus has to be in the follicular (proliferative) phase. On the basis of vaginal findings three weeks after treatment, it is be easier to decide whether ozone treatment should be treated alone or in combination with the antibiotic ceftiofur (parenterally). After the first and second intrauterine applications of ozone in cows with clinical endometritis caused by T. pyogenes, $40 \%$ and more than $80 \%$, respectively, of cured animals were recorded (SCROLLAVEZZA et al., 1997). Since the puerperal period considerably affects the fertility of cows, intrauterine ozone treatment in cases of clinical metritis and endometritis acts beneficially on overall fertility, by shortening days open in Holstein cows (ĐURIČIĆ et al., 2014) (Table 1). Antibacterial broad spectrum agents targeted for intrauterine application, in comparison to ozone preparations, lose activity in the lochia in the presence of pus and in anaerobic conditions, and may cause residua in milk and meat, and increased bacteria resistance may occur (DJURICIC et al., 2012a; 2012b; ĐURIČIĆ et al., 2014; ZOBEL et al., 2014). On the other hand, intrauterine ozone therapy may have beneficial effects on the incidence of clinical metritis and endometritis, and consequently on the improvement of reproductive efficiency, as well as lowering the costs of treatment (LEWIS, 1997; SCROLLAVEZZA et al., 1997; MARUSI et al., 2000; ZOBEL, 2013; ĐURIČIĆ et al., 2014). 
M. Samardžija et al.: Intrauterine ozone treatment of puerperal disorders in domestic ruminants: a review

Table 1. The time from the first insemination and days open until pregnancy in Holstein cows with metritis $(n=22)$, endometritis $(n=28)$ and control group $(n=41)$ (ĐURIČIĆ et al., 2014).

\begin{tabular}{|l|c|c|c|c|c|}
\hline Variables & Group & MEAN & MIN & MAX & SD \\
\hline \multirow{2}{*}{$\begin{array}{l}\text { Time until first } \\
\text { insemination p. p. }\end{array}$} & Metritis & $102.77^{\mathrm{a}}$ & 48 & 215 & 43.68 \\
\cline { 2 - 6 } & Endometritis & $106.86^{\mathrm{a}}$ & 65 & 163 & 31.78 \\
\cline { 2 - 6 } & Control & $92.85^{\mathrm{b}}$ & 45 & 187 & 32.19 \\
\hline \multirow{2}{*}{$\begin{array}{l}\text { Days open } \\
\text { until pregnancy }\end{array}$} & Metritis & $120.41^{\mathrm{a}}$ & 65 & 245 & 46.11 \\
\cline { 2 - 6 } & Endometritis & $133.50^{\mathrm{b}}$ & 89 & 241 & 31.54 \\
\cline { 2 - 6 } & Control & $125.02^{\mathrm{c}}$ & 56 & 190 & 38.43 \\
\hline
\end{tabular}

Values within the same column differ significantly with different exponent $(P<0.05)$

In cases of RFM in cows, the use of ozone, in either spray form or as paraffin pearls, has shown very positive therapeutic effects. Due to the well-recognized detrimental effects of antibiotic use, it is urgent to find a safe and effective alternative to antibiotic therapy for the treatment of RFM in ruminants. With the use of ozone between 12-24 hours (or even 36 hours) after birth, the duration of days open is comparable to those recorded in cows with physiological puerperium (DJURICIC et al., 2012a; ZOBEL and TKALCIC, 2013).

In addition, following therapy with ozone preparations for treatment of uterine infections in cows, days open and the intercalving interval are shorter, the conception rate improved, and the risk of cows being culled because of infertility decreases (DJURICIC et al., 2012a; DJURICIC et al., 2012b).

Apart from cows, ozone has been used for the first time in dairy goats with RFM, and showed similar positive effects. Dairy goats from 7 selected farms in Croatia were observed during early puerperium, and were divided into animals without RFM ( $\mathrm{n}=$ $522)$ and those with RFM $(\mathrm{n}=41)$. The selected animals were treated with either ozone foam spray $(n=21)$ or foaming oxytetracycline tablets $(n=20)$. The does with diagnosis of RFM were mated successfully and became pregnant during the next kidding season, regardless of the treatment applied. The treatment with ozone attained similar results to the standard antibiotic therapy, indicating that it could be a new potential alternative therapy for RFM in dairy goats (DJURICIC et al., 2015). In addition, ĐURIČIĆ et al. (2016) outlined a new approach to ewe reproductive tract treatment using ozone foam spray for certain obstetrical problems, such as RFM and possible uterine infections following obstetric assistance, in comparison with classical antibiotics treatments. The study was conducted on 256 ewes from 11 sheep farms in north-western Croatia. The intrauterine ozone treatment in ewes with RFM and after manual obstetrics attained similar results to spontaneously delivered ewes, showed as the physiological regression of the uterus with a similar transversal diameter without the presence of lochia in the uterine lumen, indicating that this could be also a novel potential alternative natural therapy in ewes. 
To realize the main objective of animal husbandry in diminishing negative economic trends, it is necessary to introduce contemporary management in reproduction. Among numerous preventive measures in use in practice, it is also important to use alternative preparations such as ozone, which has germicidal and fungicidal activities. Intrauterine ozone treatment in cases of clinical metritis and endometritis acts beneficially on overall fertility by shortening days open in Holstein cows. Cows treated with ozone spray 48 hours after calving became pregnant earlier and had a better conception rate. Preventive intrauterine ozone application had positive effects on reproductive performance in dairy cows. It is supposed that the foaming spray filled the entire uterus and decreased the number of bacteria by the oxidative process of ozone and peroxides that destroy the bacteria's capsule and membrane. Cows with RFM treated with an intrauterine ozone spray or ozone pearls, $\mathrm{O}_{3}$ had similar or even better reproductive performance results, in contrast to the control group of cows without RFM, which proves the effectiveness of therapy with ozone products. The intrauterine ozone treatment of RFM, using a foaming ozone spray or ozone pearls, also improved reproductive performance in Simmental cows (DJURICIC et al., 2012a). Further, we concluded that does with RFM were mated successfully and became pregnant in the next kidding season, with similar results, regardless whether they had been treated with ozone or antibiotics. This indicates that ozone could also be a new potential alternative therapy for RFM in dairy goats (ĐURIČIĆ et al., 2015).

Furthermore, the effects of ozone following application to a particular site in the organism are multiple, and result in an almost sterile microenvironment, whereas certain antibiotics may or may not be effective, and have been found to be effective only regarding bacterial pathogens. The effectiveness of ozone does not decrease in milk, intestinal content or in the uterus, where the effectiveness of certain antibiotics decreases or is totally absent. The milk of diseased animals treated with antibiotics should not be consumed for at least 3-5 days following treatment, whereas in the case of affected animals treated with ozone, the milk can be used immediately, either for industrial or nutritional purposes (SCROLLAVEZZA et al., 1997). However, there are certain limitations to ozone use in veterinary practice. In spite of its extremely strong disinfection activity, ozone is not able to inactivate intracellular bacteria and viruses, but may stimulate the immune system by activating neutrophils and enhancing the release of cytokines (BOCCI and Di PAOLO, 2004).

\section{Conclusions}

Although still insufficiently, ozone is used in human medicine for treatment of breast cancer and for wound disinfection and healing (ZOBEL et al., 2014) as well as in veterinary medicine, particularly in buiatrics reproduction. It has exhibited very promising results as an alternative to the use of antibiotics, which are being restricted or withdrawn in the production of food animals such as: cows, goats and sheep. Concerns about potential risks 
to human health, due to use/misuse of antibiotics in nonclinical practice, in production of food animals (DEWEY et al., 1997) have led to their gradual withdrawal, in accordance with EU directive 1831/2003/EC. Thus, naturally occurring bioactive substances, such as ozone, are in the focus of scientific research, but also of interest for producers and consumers (ĐURIČIĆ et al., 2015).

\section{References}

AHMAD, M., P. K. SINGH, D. K. SADANA, S. ALAM, I. D. CHALAL (2007): Reproductive performance of Beetal goats in its breeding tract. Indian J. Small Rumin. 13, 234-237.

AMEEN, S. A., J. A. AJAYI (2013): Studies on influence of seasonality on clinical conditions of small ruminants in Ogbomoso areas of Oyo State. Int. J. Appl. Agricult. Apicult. Res. 9, 18-27.

AZAWI, O. I. (2008): Postpartum uterine infection in cattle. Anim. Reprod. Sci. 105, 187-208.

BOCCI, V. A. (1996): Ozone as bioregulator: pharmacology and toxicology of ozone therapy today. J. Biol. Regul. Homeost. Agents. 10, 31-53.

BOCCI, V. A. (1999): Biological and clinical effects of ozone: Has ozone therapy a future in medicine? Br. J. Biomed. Sci. 56, 270-279.

BOCCI, V., N. Di PAOLO (2004): Oxygenation-ozonation of blood during extracorporeal circulation (EBOO). III. A new medical approach, ozone. Science 26, 195-205.

DEWEY, C. E., B. D. COX, B. E. STRAW, E. J. BUSH, H. S. HURD (1997): Associations between off-label feed additives and farm size, veterinary consultant use, and animal age. Prev. Vet. Med. 31, 133-146.

Di PAOLO, N., V. BOCCI, E. GAGGIOTI (2004): Ozone therapy editorial review. Int. J. Artificial Organs 27, 168-175.

DINSMORE, R. P., R. D. STEVENS, M. B. CATTELL, M. D. SALMAN, S. F. SUNDLOF (1996): Oxytetracycline residues in milk after intrauterine treatment of cows with retained fetal membranes. J. Am. Vet. Med. Assoc. 209, 1753-1755.

DJURICIC, D., S. VINCE, M. ABLONDI, T. DOBRANIC, M. SAMARDZIJA (2012a): Intrauterine ozone treatment of retained fetal membrane in Simmental cows. Anim. Reprod. Sci. 134, 119-124.

DJURICIC, D., S. VINCE, M. ABLONDI, T. DOBRANIC, M. SAMARDZIJA (2012b): Effect of preventive intrauterine ozone application on reproductive efficiency in Holstein cows. Reprod. Domest. Anim. 47, 87-91.

DJURICIC, D., S. VINCE, J. GRIZELJ, T. DOBRANIC, M. LIPAR, M. SAMARDZIJA (2011): Influence of different therapy approaches - with or without manual extraction - of retained placenta on reproductive performance in Simmental cows. Acta Vet. (Beograd) 61, 599-608.

DJURICIC, D., H. VALPOTIC, M. SAMARDZIJA (2015): The intrauterine treatment of retained foetal membrane in dairy goats by ozone: novel alternative to antibiotic therapy. Reprod. Domest. Anim. 50, 236-239.

DOBRANIĆ, T., M. SAMARDŽIJA, V. DOBRANIĆ, S. VINCE, D. GRAČNER, N. STAKLAREVIĆ, J. GRIZELJ, N. PRVANOVIĆ, Z. ŽVORC (2008): Analyse der 
M. Samardžija et al.: Intrauterine ozone treatment of puerperal disorders in domestic ruminants: a review

Ovarienaktivität der Holstein-Friesicher Kühe im Puerperium mit Hilfe des Stoffwechsel- und Hormonprofils. Tierärztl. Umschau 63, 65-71.

DRILliCH, M., O. BEETZ, A. PFÜTZNER, M. SABIN, H. J. SABIN, P. KUTZER, H. NATTERMANN, W. HEUWIESER (2001): Evaluation of a systemic antibiotic treatment of toxic puerperal metritis in dairy cows. J. Dairy Sci. 84, 2010-2017.

ĐURIČIĆ, D., J. GRIZELJ, T. DOBRANIĆ, I. HARAPIN, S. VINCE, P. KOČILA, I. FOLNOŽIĆ, M. LIPAR, G. GREGURIĆ GRAČNER, M. SAMARDŽIJA(2012): Reproductive performance of Boer goats in a moderate climate zone. Vet. arhiv 82, 351-358.

ĐURIČIĆ, D., M. LIPAR, M. SAMARDŽIJA (2014): Ozone treatment of metritis and endometritis in Holstein cows. Vet. arhiv 84, 103-110.

ĐURIČIĆ, D., H. VALPOTIĆ, M. SAMARDŽIJA (2015): Prophylaxis and therapeutic potentials of ozone in buiatrics: Current knowledge. Anim. Reprod. Sci. 159, 1-7.

ĐURIČIĆ, D., H. VALPOTIĆ, I. ŽURA ŽAJA, M. SAMARDŽIJA (2016): Comparison of intrauterine antibiotics versus ozone medical use in sheep with retained placenta and following obstetric assistance. Reprod. Domest. Anim. 51, 538-540.

EILER, H. (1997): Retained placenta. In: Current therapy in large animal theriogenology. (Youngquist, R. S. Ed.) W. B. Saunders Company, Philadelphia, PA. pp. 340-348.

FOLNOŽIĆ, I., R. TURK, D. ĐURIČIĆ, S. VINCE, J. PLEADIN, Z. FLEGAR-MEŠTRIĆ, H. VALPOTIĆ, T. DOBRANIĆ, D. GRAČNER, M. SAMARDŽIJA (2015): Influence of body condition on serum metabolic indicators of lipid mobilization and oxidative stress in dairy cows during the transition period. Reprod. Domest. Anim. 50, 910-917.

GAUTAM, G., T. NAKAO, M. YUSUF, K. KOIKE (2009): Prevalence of endometritis during the postpartum period and its impact on subsequent reproductive performance in two Japanese dairy herds. Anim. Reprod. Sci. 116, 175-187.

GONZÁLEZ, F. D., R. MUIÑO, V. PEREIRA, R. CAMPOS, J. L. BENEDITO (2011): Relationship among blood indicators of lipomobilization and hepatic function during early lactation in highyielding dairy cows. J. Vet. Sci. 12, 251-255.

OZMEN, V., W. O. THOMAS, J. T. HEALY, J. M. FISH, R. CHAMBERS, E. TACCHI, R. L. NICHOLS, L. M. FLINT, J. J. FERRARA (1993): Irrigation of the abdominal cavity in the treatment of experimentally induced microbial peritonitis: efficacy of ozonated saline. Am. Surg. J. 59, 297-303.

KOČILA, P., M. SAMARDŽIJA, T. DOBRANIĆ, D. GRAČNER, V. DOBRANIĆ, N. PRVANOVIĆ, Ž. ROMIĆ, N. FILIPOVIĆ, N. VUKOVIĆ, D. ĐURIČIĆ (2009): Einfluss der Energiebilanz auf die Reproduktionsfähigkeit von Holsteiner Kühen im Puerperium. Tierärztl. Umschau 64, 471-477.

KORZUN, W., J. HALL, R. SAUER (2008): The effect of ozone on common environmental fungi. Clin. Lab. Sci. 21, 107-111.

LAVEN, R. A., A. R. PETERS (1996): Bovine retained placenta: Aetiology, pathogenesis and economic loss. Vet. Rec. 139, 465-471.

LeBLANC, S. J. (2010): Monitoring metabolic health of dairy cattle in the transition period. J. Reprod. Dev. 56, Suppl. S29-S35. 
M. Samardžija et al.: Intrauterine ozone treatment of puerperal disorders in domestic ruminants: a review

LeBLANC, S. J. (2008): Postpartum uterine disease and dairy herd reproductive performance: a review. Vet. J. 176, 102-114.

LEWIS, G. S. (1997): Uterine health and disorders. J. Dairy Sci. 80, 984-994.

LOPEZ-GATIUS, F., I. GARCIA-ISPIERTO, P. SANTOLARIA, J. YANIZ, C. NOGAREDA, M. LOPEZ-BEJAR (2006): Screening for high fertility in high-producing dairy cows. Theriogenology 65, 1678-1689.

MARUSI, A., M. ALLEGRI, G. MARASI, G. ORSI, A. UBALDI (1999): I lipoperossidi nella profilassi e terapia della metrite e nel miglioramento della fertilità nella bovina da latte. Atti Soc. It. Buiatria, Bologna.

MARUSI, A., A. UBALDI, A. FUSARI, G. MARASI, F. ISNENGHI (2000): Haptoglobin response in dairy cow metritis treatment with lipohydroperoxides. XXI World Buiatrics Congress, Punta del Este Uruguay, 4-8 December.

MATEUS, L., L. LOPES DA COSTA, H. CARVALHO, P. SERRA, J. ROBALO SILVA (2002): Blood and intrauterine leukocyte profile and function in dairy cows that spontaneously recovered from postpartum endometritis. Reprod. Domest. Anim. 37, 176-180.

MATTHEWS, J. G. (2009): Diseases of the goat. Blackwell publishing Ltd., $3^{\text {rd }}$ ed., Oxford, UK.

MUDE, S. W., S. P. WAGHMARE (2010): Effect of mineral supplementation on post-parturient diseases in pregnant goats. Vet. World 3, 109-110.

NOAKES, D. E., J. P. TIMOTHY, G. C. W. ENGLAND, G. H. ARTHUR (2009): Infertility and subfertility in the cows. In: Arthur's Veterinary Reproduction and Obstetrics. WB Saunders Publisher, New York, USA.

OHTSUKA, A., N. OGATA, M. TERASAKI, S. KOIWA (2006): Changes in leukocyte population after ozonated autohemoadministration in cows with inflammatory diseases. J. Vet. Med. Sci. $68,175-178$.

PRYCE, J. E., M. D. ROYAL, P. C. GARNSWORTHY, I. L. MAO (2004): fertility in the highproducing dairy cow. Livestock Prod. Sci. 86, 125-135.

SAMARDŽIJA, M., D. ĐURIČIĆ, T. DOBRANIĆ, M. HERAK, S. VINCE (2010): Reproduction of sheep and goats. In: Puerperium- retention of fetal membranes. (Samardžija, M., M. Poletto, Eds.):Faculty of Veterinary Medicine University of Zagreb. pp. 293-295 (in Croatian).

SAMARDŽIJA, M., T. DOBRANIĆ, S. VINCE, V. DOBRANIĆ, J. GRIZELJ, M. KARADJOLE, D. GRAČNER, LJ. BEDRICA, Z. ŽVORC (2008): Einfluss der Milchleistung auf die Fruchtbarkeitsstörungen bei Kühen im Puerperium. Tierärtzl. Umschau 63, 123-127.

SASSI, G., S. ISMAIL, Á. CS. BAJCSY, G. KISS, A. RÉPÁSI, O. SZENCI (2010): Evaluation of the alternatives of the intrauterine antibiotic treatments in the cow: Literature review. Magy Állatorv. Lapja 132, 516-527.

SCROLLAVEZZA, P., M. ABLONDI, B. POGLIACOMI, D. GUARESCHI, R. DALL'AGLIO, R. POLDI, et al. (1997): Ozone treatment in mastites, metrites and retention of fetal membranes in the cows. Atti $2^{\circ}$ Intern. Symp. Ozone Application, Havana, Cuba. 
M. Samardžija et al.: Intrauterine ozone treatment of puerperal disorders in domestic ruminants: a review

SHELDON, I. M., M. BUSHNELL, J. MONTGOMERY, A. N. RYCROFT (2004): Minimum inhibitory concentrations of some antimicrobial drugs against bacteria causing uterine infections in cattle. Vet. Rec. 15, 383-387.

SHELDON, I. M., H. DOBSON (2004): Postpartum uterine health in cattle. Anim. Reprod. Sci. 82-83, 295-306.

SHELDON, I. M., G. S. LEWIS, S. J. LEBLANC, R. O. GILBERT (2006): Defining postpartum uterine disease. Theriogenology 65, 1516-1530.

SONG, H. B., I. H. JO, H. S. SOL (2006): Reproductive performance of Korean native goats under natural and intensive conditions. Small Rumin. Res. 65, 284-287.

SZENCI, O., D. BUJÁK, Á. CS. BAJCSY, A. HORVÁTH, B. HAN, Z. SZELÉNYI (2015): Diagnosis and treatment of post parturient uterine diseases in dairy cows. Magy Állatorv. Lapja 137, 271-282.

SZENCI, O. (2014): Diagnosis and treatment of post-parturient uterine diseases in the dairy cow In: Proceedings of the XXVIII World Buiatrics Congress. (Beggs, D. S., Ed.). Australian Cattle Veterinarians, Cairns, Australia. pp. 274-280.

TRAVAGLI, V., I. ZANARDI, V. BOCCI (2009): Topical applications of ozone and ozonated oils as anti-infective agents: an insight into the patent claims. Recent patents on anti-infective drug discover 4, 130-142.

VAN WERVEN, T., Y. H. SCHUKKEN, J. LLOYD, A. BRAND, H. HEERINGA, M. SHEA (1992): The effect of duration of retained placenta on reproduction, milk production, postpartum disease and culling rate. Theriogenology 37, 1191-1203.

WEIGEL, K. A. (2006): Prospects for improving reproductive performance through genetic selection. Anim. Reprod. Sci. 96, 3223-3230.

ZOBEL, R. (2013): Endometritis in Simmental cows: incidence, causes, and therapy options. Turk J. Vet. Anim. Sci. 37, 134-140.

ZOBEL, R., G. JURIČIĆ, M. PERAK (2014): Ozone in veterinary medicine: A review article. Hrv. vet. vjesnik 22, 38-42.

ZOBEL, R., S. TKALCIC (2013): Efficacy of ozone and other treatment modalities for retained placenta in dairy cows. Reprod. Domest. Anim. 48, 121-125.

Received: 19 January 2016

Accepted: 26 April 2016

SAMARDŽIJA, M., R. TURK, P. SOBIECH, H. VALPOTIĆ, I. HARAPIN, D. GRAČNER, D. ĐURIČIĆ: Intrauterino liječenje puerperalnih poremećaja domaćih preživača ozonom - pregledni članak. Vet. arhiv 87, 363-375, 2017. SAŽETAK

Zajedničkim naporima temeljnih i kliničkih veterinarskih znanstvenika i stručnjaka te uzgajivača domaćih životinja, protumikrobni lijekovi prirodnog podrijetla unijet će u veterinarsku medicinu isti oblik terapijske revolucije kakav se danas pripisuje antibioticima u borbi protiv zaraznih bolesti. To je od posebne važnosti u reprodukcijskom managementu u govedarstvu gdje je ozon rabljen kao alternativa antibioticima zbog svoje 
M. Samardžija et al.: Intrauterine ozone treatment of puerperal disorders in domestic ruminants: a review

germicidne i fungicidne djelotvornosti. U veterinarskoj medicini ozon je najčešće rabljen za profilaksu i terapiju patoloških stanja spolnog sustava domaćih preživača, kao što su zaostajanje posteljice, klinički metritis $\mathrm{i}$ endometritis te za unapređivanje plodnosti prema navodima nekih prethodnih istraživanja. Prednosti ozona u usporedbi s antibioticima su: uporaba bez recepta, niski troškovi liječenja, izostajanje bakterijske rezistencije te odsutnost rezidua $u$ animalnim proizvodima. Može se zaključiti da je ozon često rabljen u veterinarskoj praksi posebice u bujatrici, ali još uvijek nedostatno. Naime, pokazao je vrlo obećavajuće rezultate u liječenju puerperalnih poremećaja u krava, koza i ovaca kao alternativa uporabi antibiotika, čija je primjena ograničena ili zabranjena u proizvodnji konzumnih životinja.

Ključne riječi: liječenje, ozon, puerperalni poremećaji, preživači 
